\title{
SIFAT ORGANOLEPTIK DAGING AYAM PETELUR TUA YANG DIRENDAM DALAM EKSTRAK KULIT NANAS (Ananas comosus L. Merr)
}

\author{
Ahmad Dewanto, M. D. Rotinsulu*, T. A. Ransaleleh, R. M. Tinangon \\ Fakultas Peternakan Universitas Sam Ratulangi Manado 95115
}

\begin{abstract}
ABSTRAK
Tujuan dari penelitian ini untuk mengetahui sifat organoleptik daging ayam petelur tua yang direndam dalam ekstrak kulit nanas (Ananas comusus L. Merr). Materi yang digunakan adalah daging bagian dada ayam petelur tua sebanyak 25 ekor berumur 24 bulan dan kulit nanas sebanyak 10 buah. Penelitian ini menggunakan Rancangan Acak Lengkap dan pengukuran uji organoleptik dengan menggunakan skala hedonik, menggunakan penelis tidak terlatih sebanyak 40 orang. Sebagai perlakuan dalam penelitian ini adalah waktu perendaman daging ayam petelur tua dalam ekstrak kulit nanas yang disusun sebagai berikut:

R0 = Tanpa perendaman dalam ekstrak kulit nanas

$\mathrm{R} 1$ = Perendaman dalam ektrak kulit nanas selama 1 jam

R2 = Perendaman dalam ektrak kulit nanas selama 2 jam

R3 = Perendaman dalam ektrak kulit nanas selama 3 jam

R4 = Perendaman dalam ektrak kulit nanas selama 4 jam

Analisis sidik ragam untuk uji organoleptik menunjukkan perlakuan perendaman dalam ekstrak kulit nanas memberikan pengaruh sangat nyata $(\mathrm{P}<0.01)$ terhadap warna, aroma, keempukan, tektur, citarasa daging ayam petelur tua. Berdasarkan hasil analisa data

*Korespondensi (corresponding Author)

Email: merrirot@gmail.com
\end{abstract}

pembahasan untuk semua variabel maka dapat disimpulkan sifat organoleptik daging ayam petelur tua yang disukai panelis untuk tekstur dan keempukan adalah yang direndam selama satu jam pada ekstrak kulit nanas sedangkan untuk warna, aroma dan rasa adalah yang tanpa perendaman.

Kata kunci: Daging Ayam, Kulit Nanas, Organoleptik.

\section{ABSTRACT}

The objective of this study was to evaluate the organoleptic characteristic of old laying meat immersed in pineapple peel extract (Ananas comusus L. Merr). The materials used in this study were 25 birds of the age of 24 months old and the extract of 10 pineapple peels. The Completely Randomized Design was applied in this study, involving the organoleptic test measurement with hedonic scale and untrained panelist of 40 peoples. Treatments were involving immersion of old laying meat in pineapple peel extract with levels :

$\mathrm{R} 0=$ Without immersion in pineapple peel extract

$\mathrm{R} 1$ = Immersion in pineapple peel extract during 1 hour

$\mathrm{R} 2=$ Immersion in pineapple peel extract during 2 hours

$\mathrm{R} 3=$ Immersion in pineapple peel extract during 3 hours

$\mathrm{R} 4=$ Immersion in pineapple peel extract during 4 hours 
Analysis of variance were used for organoleptic test and showed that treatments affected significantly $(\mathrm{P}<0.01)$ the colour, flavour, tenderness, texture, and taste of ald laying meat. Study indicated that panelists preferred the texture and tenderness of laying meat immersed during one hour in pineapple extract however they preferred the meat colour and taste without immersion.

Keywords: Laying meat, pineapple peel, organoleptic

\section{PENDAHULUAN}

Daging dapat diperoleh dari ayam petelur tua berumur kira-kira 72-80 minggu pada akhir masa produksi telur atau produksi telur yang dihasilkan telah mengalami penurunan. Pemanfaatan daging ayam petelur tua masih sangat kurang jika dibandingkan dengan ayam broiler ataupun ayam buras disebabkan daging ayam petelur tua mempunyai sifat lebih alot (Subekti, 2010). Menurut Soeparno (2015), penyebabnya adalah tingginya kandungan kolagen dan jumlah ikatan silang intermolekuler antar benangbenang kolagen. Kolagen dapat mempengaruhi keempukan daging bila terdapat dalam jumlah yang besar di dalam otot dan mengalami perubahan molekuler selama perkembangan kedewasaan ternak. Kealotan daging dapat diatasi dengan pemberian enzim yang dapat meningkatkan keempukan. Pengempukan secara enzimatis merupakan metode pengempukan yang mudah dilakukan (Rugayah, 2008).

Enzim yang bekerja sebagai katalis dalam reaksi hidrolisis protein disebut enzim proteolitik (Naiola dan Widyastuti, 2007). Banyak varietas nanas (Ananas comosus L. Merr) yang termasuk dalam famili bromeliaseae mengandung enzim proteolitik yang disebut bromelin (Wuryanti, 2004). Enzim bromelin dapat diisolasi dari daging buah, kulit buah, bonggol, tangkai daun, dan daun (Suhermiyati dan Sylvia, 2005). Bromelin termasuk golongan enzim proteolitik yang lokasi aktifnya adalah gugus sulfhidril pada protein (polipeptida). Adapun asam amino yang memiliki gugus sulfhidril adalah metionin dan sistein (Mashuri, 2014). Kulit nanas sebagai limbah dapat diekstrak dan dimanfaatkan dalam pengempukan dengan cara merendam daging ayam petelur tua. Kulit nanas memiliki kandungan enzim bromelin dengan aktivitas optimum pada temperatur $65^{\circ} \mathrm{C}$ dan pada $\mathrm{pH} \quad 6,5$ (Kumaunang dan Kamu, 2011) adapun menurut Sebayang (2006), temperatur optimal enzim bromelin adalah $60^{\circ} \mathrm{C}$. Menurut Zulfahmi (2010), Perendaman daging ayam afkir dengan ekstrak kulit nanas (Ananas comosus L. Merr) pada konsentrasi $27,5 \%$ dapat meningkatkan keempukan serta menurunkan daya ikat air dan $\mathrm{pH}$, namun tidak menyebabkan peningkatan kadar air, warna dan aroma. 
Menurut Purnamasari et al. (2014), level konsentrasi ektrak kulit nanas $100 \%$ dapat meningkatkan kadar protein daging ayam afkir.

Penilaian organoleptik dapat digunakan untuk menentukan kualitas dan membuat keputusan dalam mengkonsumsi daging ayam petelur tua. Berdasarkan permasalahan diatas maka dilakukan penelitian tentang sifat organoleptik daging ayam petelur tua yang direndam dalam ekstrak kulit nanas.

\section{MATERI DAN METODE PENELITIAN}

\section{Waktu dan Tempat Penelitian}

Penelitian ini dilakukan sejak tanggal 1 sampai 26 November 2016, bertempat di Laboratorium Teknologi Hasil Ternak Fakultas Peternakan Universitas Sam Ratulangi Manado.

\section{Materi Penelitian}

Ayam petelur tua berkisar 24 bulan sebanyak 25 ekor diambil daging bagian dada dan ditimbang sebanyak 10 gram dengan ukuran $2 \times 2 \times 1 \mathrm{~cm}$ sebanyak 40 potongan. Buah nanas sebanyak 10 buah diambil kulitnya dan diekstraksi. Peralatan yang digunakan timbangan digital (Kris
Chef Ek9350H), blender (Miyako BL-101 PL 2in1), thermometer bimetal (Probe besi $0-100^{\circ} \mathrm{C}$ ), water bath (Thermologic model BW 81 Seri no. 8603036), pisau, baskom, saringan, format uji dan perlengkapan.

\section{Metode Penelitian}

Penelitian ini dirancang dengan menggunakan Rancangan Acak Lengkap (RAL) dengan 5 perlakuan (Steel and Torrie, 1995), sebagai ulangan digunakan panelis tidak terlatih sebanyak 40 orang. Perlakuan adalah perendaman daging ayam petelur tua dalam ekstrak kulit nanas pada suhu kamar yang terdiri dari 5 perlakuan yakni :

$\mathrm{R} 0$ = Tanpa perendaman dalam ekstrak kulit nanas

$\mathrm{R} 1$ = Perendaman dalam ektrak kulit nanas selama 1 jam

R2 = Perendaman dalam ektrak kulit nanas selama 2 jam

R3 = Perendaman dalam ektrak kulit nanas selama 3 jam

R4 = Perendaman dalam ektrak kulit nanas selama 4 jam

Untuk diagram proses pembuatan ekstrak nenas dapat dilihat pada gambar 1. Sedangkan untuk pemberian ekstrak dapat dilihat pada gambar 2 . 


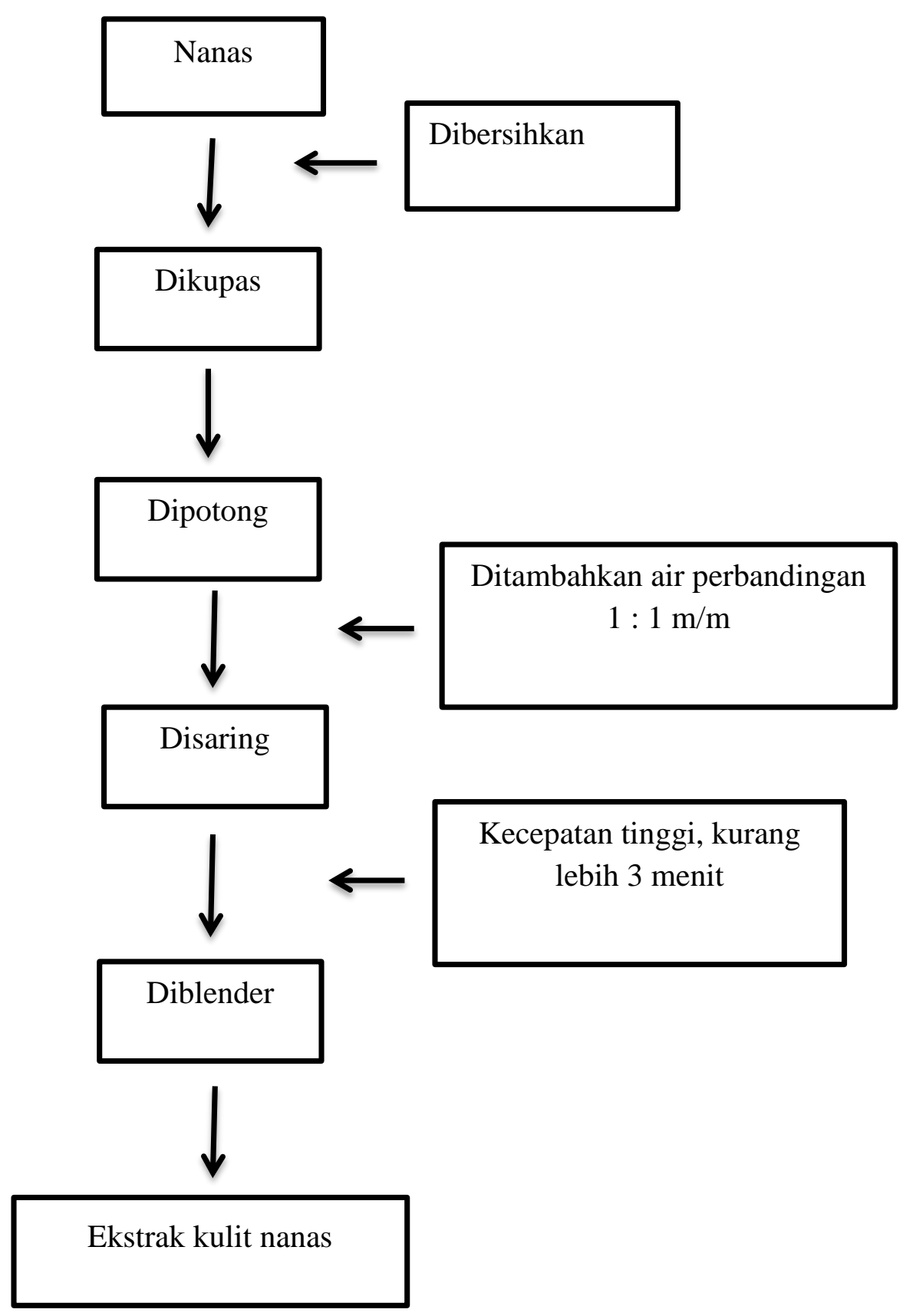

Gambar 1. Diagram Alir Proses Pembuatan Ekstrak Kulit Nanas 

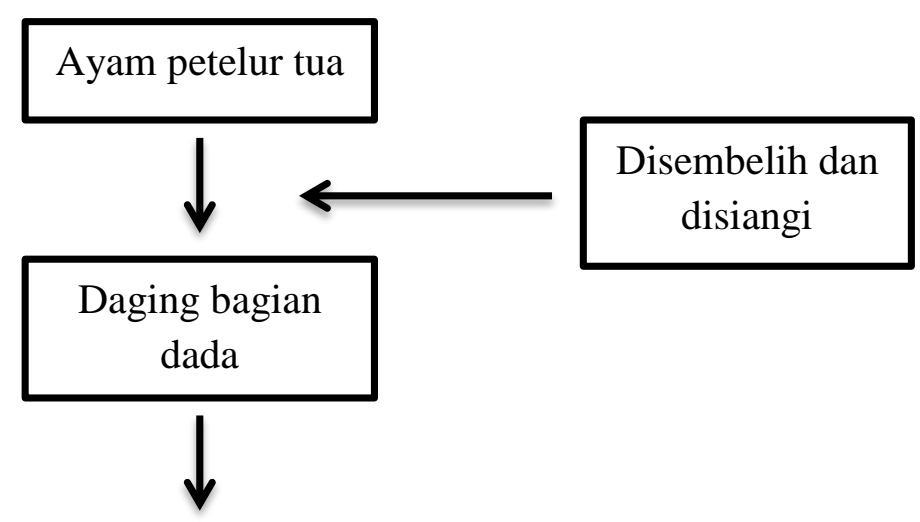

Dibersihkan

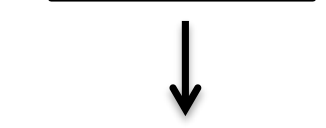

Dipotong ukuran

$10 \mathrm{~g}(2 \times 2 \times 1 \mathrm{~cm})$

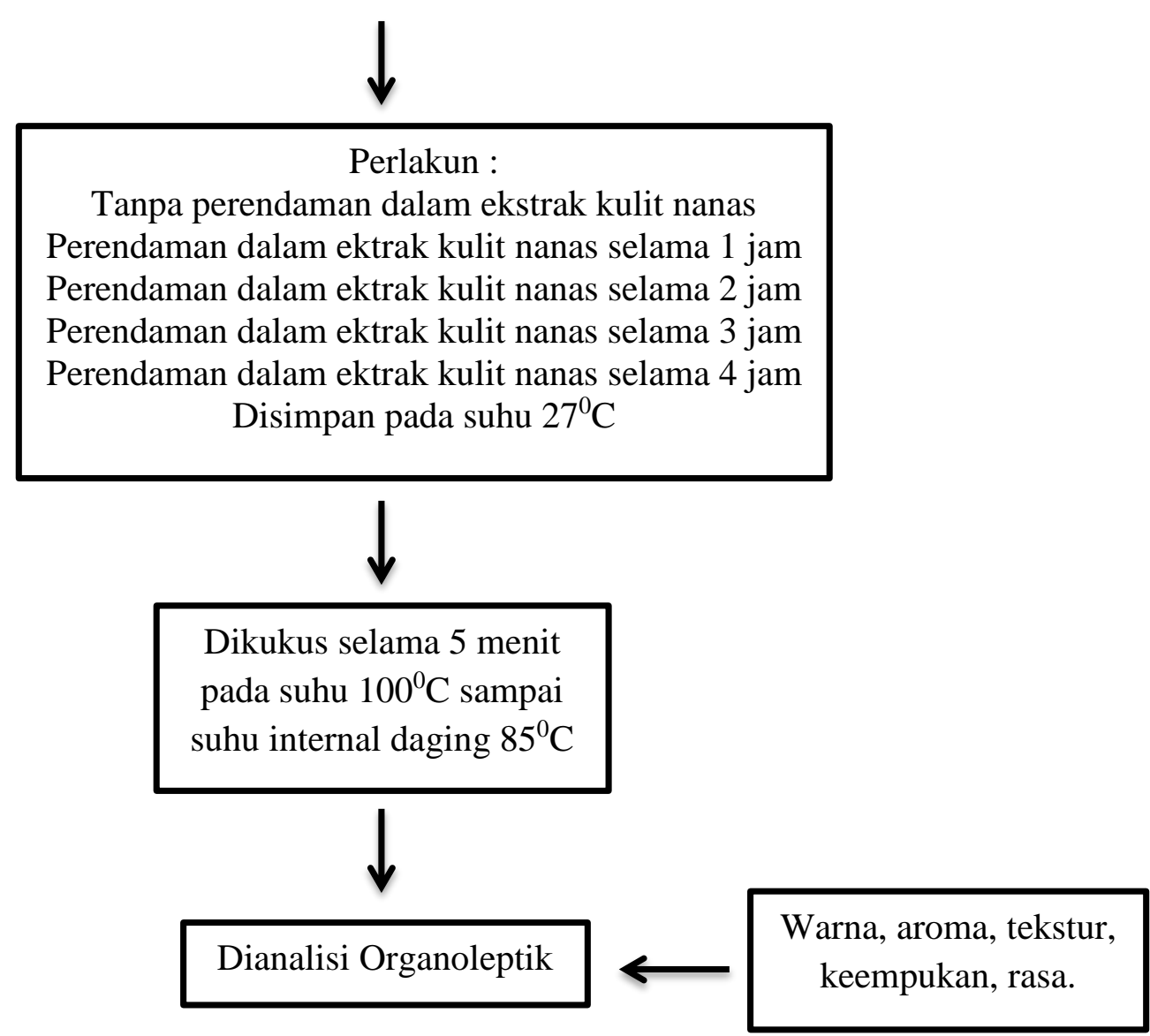

Gambar 2. Diagram Alir Pemberian Ekstrak Kulit Nanas Pada Daging Ayam Petelur Tua 


\section{Variabel}

Variabel yang diamati adalah sifat organoleptik daging yaitu warna, aroma, keempukan, tekstur dan citarasa. Format uji dapat dilihat pada lampiran 2. Penelitian ini menggunakan uji organoleptik dengan skala hedonik 1 sampai 7, panelis yang digunakan adalah panelis tidak terlatih yaitu 40 orang.

Skala hedonik yang digunakan adalah sebagai berikut:

7 = Sangat suka sekali

6 = Sangat suka

$5=$ Suka

4 = Agak suka

$3=$ Agak tidak suka

2 = Tidak suka

$1=$ Sangat tidak suka sekali

\section{HASIL DAN PEMBAHASAN}

Hasil pengamatan sifat organoleptik daging ayam petelur tua yang direndam dalam ekstrak kulit nanas disajikan dalam Tabel 1.

\section{Warna Daging}

Hasil pengamatan warna daging dapat dilihat pada Tabel 1. Data menunjukkan bahwa tingkat kesukaan panelis terhadap warna daging dengan lama perendaman yang berbeda dan pada kisaran 3.60 (agak suka) sampai 4.60 (suka).
Hasil sidik ragam menunjukkan bahwa perlakuan lama perendaman daging ayam petelur tua dalam ekstrak kulit nanas berbeda sangat nyata $(\mathrm{P}<0.01)$ terhadap warna daging. Hasil uji lanjut menggunakan uji wilayah berganda Duncan menunjukkan bahwa perlakuan R0 tidak berbeda nyata $(\mathrm{P}>0.05)$ terhadap $\mathrm{R} 1$, R2 dan R3 tetapi berbeda sangat nyata $(\mathrm{P}<0.01)$ terhadap R4. Perlakuan lama perendaman R1 tidak berbeda nyata ( $\mathrm{P}>0.05$ ) terhadap R2 dan R3 tetapi berbeda sangat nyata $(\mathrm{P}>0.01)$ terhadap $\mathrm{R} 4$. Perlakuan lama perendaman R2 tidak berbeda nyata $(\mathrm{P}>0.05)$ terhadap $\mathrm{R} 3$ dan R4. Perlakuan perendaman R3 tidak berbeda sangat $(\mathrm{P}>0.05)$ terhadap $\mathrm{R} 4$. Perlakuan lama perendaman R4 berbeda sangat nyata $(\mathrm{P}<0.01)$ terhadap $\mathrm{R} 0$ dan $\mathrm{R} 1$ tetapi tidak berbeda nyata $(\mathrm{P}>0.05)$ terhadap R2 dan R3. Dari data yang dihasilkan dapat diketahui bahwa semakin lama perendaman daging ayam petelur tua dalam ekstrak kulit nanas maka tingkat kesukaan terhadap warna daging ayam petelur tua semakin menurun, hal ini disebabkan semakin lama perendaman maka semakin banyak enzim bromelin masuk dalam daging yang membuat ikatan mioglobin terurai. Terurainya ikatan mioglobin merubah warna merah daging 
Tabel 1. Rataan Sifat Organoleptik Daging Ayam Petelur Tua Yang Direndam Dalam Estrak Kulit Nanas (Ananas comosus L. Merr)

\begin{tabular}{lccccc}
\hline \multirow{2}{*}{ Variabel } & \multicolumn{5}{c}{ Perlakuan Lama Perendaman } \\
\cline { 2 - 6 } & $\mathrm{R} 0$ & $\mathrm{R} 1$ & $\mathrm{R} 2$ & $\mathrm{R} 3$ & $\mathrm{R} 4$ \\
\hline Warna & $4.60^{\mathrm{a}}$ & $4.45^{\mathrm{ab}}$ & $4.03^{\mathrm{abc}}$ & $4.08^{\mathrm{abc}}$ & $3.60^{\mathrm{c}}$ \\
Aroma & $4.55^{\mathrm{a}}$ & $3.90^{\mathrm{ab}}$ & $4.13^{\mathrm{ab}}$ & $4.13^{\mathrm{ab}}$ & $3.13^{\mathrm{c}}$ \\
Keempukan & $3.83^{\mathrm{a}}$ & $4.93^{\mathrm{b}}$ & $4.33^{\mathrm{ac}}$ & $4.05^{\mathrm{acd}}$ & $3.53^{\mathrm{ad}}$ \\
Tekstur & $3.78^{\mathrm{a}}$ & $4.95^{\mathrm{b}}$ & $4.433^{\mathrm{cd}}$ & $3.93^{\mathrm{ad}}$ & $3.05^{\mathrm{e}}$ \\
Rasa & $4.63^{\mathrm{a}}$ & $3.23^{\mathrm{bcde}}$ & $3.08^{\mathrm{cde}}$ & $3.03^{\mathrm{de}}$ & $2.63^{\mathrm{e}}$ \\
\hline
\end{tabular}

Keterangan : Superskrip berbeda pada baris yang sama artinya berbeda sangat nyata $(\mathrm{P}<0,01)$

menjadi pucat menyebabkan tingkat kesukaan panelis terhadap warna daging menurun, warna daging ayam petelur tua setelah direndam dalam ekstrak kulit nanas adalah putih. Hadiwiyoto (1992), menyatakan bahwa daging unggas mengandung mioglobin yang mudah terdegradasi dan terhidrolisis sehingga warna daging berubah. Pemberian air buah nanas terhadap daging akan menyebabkan warnanya semakin pucat seiring dengan bertambahnya lama pemberian air buah nanas (Fenita et al., 2009).

\section{Aroma Daging}

Hasil pengamatan aroma daging dapat dilihat pada Tabel 1. Data menunjukkan bahwa tingkat kesukaan panelis terhadap aroma daging dengan lama perendaman yang berbeda dan pada kisaran 3.13 (agak tidak suka) sampai 4.55 (agak suka).

Hasil sidik ragam menunjukkan bahwa perlakuan lama perendaman daging ayam petelur tua dalam ekstrak kulit nanas berbeda sangat nyata $(\mathrm{P}<0.01)$ terhadap aroma daging. Hasil uji lanjut menggunakan uji wilayah berganda Duncan menunjukkan bahwa perlakuan R0 tidak berbeda nyata $(\mathrm{P}>0.05)$ terhadap $\mathrm{R} 2$ dan $\mathrm{R} 3$ tetapi berbeda nyata $(\mathrm{P}<0.05)$ terhadap R1 dan R4. Lama perendaman R1 tidak berbeda nyata $(\mathrm{P}>0.05)$ terhadap $\mathrm{R} 2$ dan R3 tetapi berbeda sangat nyata $(\mathrm{P}<0.01)$ terhadap $\mathrm{R} 4$. Lama perendaman $\mathrm{R} 2$ tidak berbeda nyata $(\mathrm{P}>0.05)$ terhadap R3 tetapi berbeda sangat nyata $(\mathrm{P}<0.01)$ terhadap R4. Lama perendaman R3 tidak berbeda nyata $(\mathrm{P}>0.05)$ terhadap $\mathrm{R} 4$. Perlakuan R4 berbeda sangat nyata $(\mathrm{P}<0.01)$ terhadap R0, R1, R2, dan R3. Dari 
data dihasilkan dapat diketahui bahwa semakin lama perendaman daging ayam petelur tua dalam ekstrak kulit nanas maka tingkat kesukaan terhadap aroma daging ayam petelur tua semakin menurun. Hal ini disebabkan semakin lama perendaman maka protein menjadi terurai yang mempengaruhi senyawa-senyawa volatil terlepas. Menurut Warris (2000) dalam Fernando (2007), aroma atau bau dihasilkan dari substansi-substansi volatil yang ditangkap oleh reseptor penciuman yang ada di belakang hidung yang selanjutnya diinterpretasikan oleh otak.

\section{Keempukan Daging}

Hasil pengamatan keempukan daging dapat dilihat pada Tabel 1. Data menunjukkan bahwa tingkat kesukaan panelis terhadap keempukan daging dengan lama perendaman yang berbeda dan pada kisaran 3.53 (agak tida suka) sampai 4.93 (suka).

Hasil sidik ragam menunjukkan bahwa perlakuan lama perendaman daging ayam petelur tua dalam ekstrak kulit nanas berbeda sangat nyata $(\mathrm{P}<0.01)$ terhadap keempukan daging. Hasil uji lanjut menggunakan uji wilayah berganda Duncan menunjukkan bahwa perlakuan R0 berbeda nyata $(\mathrm{P}<0,05)$ terhadap $\mathrm{R} 1$ dan $\mathrm{R} 2$ tetapi tidak berbeda nyata $(\mathrm{P}>0.05)$ terhadap R3 dan R4. Lama perlakuan R1 berbeda sangat nyata $(\mathrm{P}<0.01)$ terhadap $\mathrm{R} 2$, R3 dan R4. Lama perlakuan R2 berbeda sangat nyata $(\mathrm{P}<0.01)$ terhadap $\mathrm{R} 3$ tetapi tidak berbeda nyata $(\mathrm{P}>0.05)$ terhadap $\mathrm{R} 4$. Lama perlakuan $\mathrm{R} 3$ berbeda nyata $(\mathrm{P}<0.05)$ terhadap R4. Perlakuan R4 tidak berbeda nyata $(\mathrm{P}>0.05)$ terhadap $\mathrm{R} 0$ tetapi berbeda nyata $(\mathrm{P}<0.05)$ terhadap $\mathrm{R} 1, \mathrm{R} 2$ dan $\mathrm{R}$. Dari data hasil analisis dapat dilihat terjadi peningkatan tingkat kesukaan panelis terhadap keempukan daging ayam petelur tua pada lama perendaman R1, R2, R3 tetapi terjadi penurun tingkat kesukaan pada R4. Dapat diketahui perendaman daging ayam petelur tua dalam ekstrak kulit nanas selama satu jam sudah mampu memutuskan ikatan peptida. Hal ini disebabkan semakin lama perendaman menyebabkan ekstrak kulit nanas yang mengandung bromelin makin banyak masuk ke dalam daging dan bekerja memutus ikatan gugus sulfida dan ikatan polipeptida terhidrolisis sehingga daging menjadi empuk. Ha et al. (2012) menyatakan enzim protease dapat menghidrolisis ikatan kolagen daging pada otot, sehingga menyebabkan hilangnya ikatan antar serat dan juga pemecahan serat menjadi fragmen yang lebih pendek dan menjadikan sifat serat otot lebih mudah terpisah sehingga daging semakin empuk. 


\section{Tekstur Daging}

Hasil pengamatan tekstur daging dapat dilihat pada Tabel 1. Data menunjukkan bahwa tingkat kesukaan panelis terhadap tekstur daging dengan lama perendaman yang berbeda dan pada kisaran rataan 3.05 (agak tidak suka) sampai 4.95 (suka).

Hasil sidik ragam menunjukkan bahwa perlakuan lama perendaman daging ayam petelur tua dalam ekstrak kulit nanas berbeda sangat nyata $(\mathrm{P}<0.01)$ terhadap keempukan daging. Hasil uji lanjut menggunakan uji wilayah berganda Duncan (Lampiran 6c) menunjukkan bahwa perlakuan R0 berbeda sangat nyata $(\mathrm{P}<0.01)$ terhadap $\mathrm{R} 1, \mathrm{R} 2$ dan $\mathrm{R} 4$ tetapi tidak berbeda nyata $(\mathrm{P}>0.05)$ terhadap $\mathrm{R} 3$. Lama perendaman $\mathrm{R} 1$ berbeda nyata $(\mathrm{P}<0.05)$ terhadap $\mathrm{R} 2$, R3 dan $\mathrm{R} 4$. Lama perlakuan R2 berbeda nyata $(\mathrm{P}<0.05)$ terhadap R3 dan R4. Lama perlakuan R3 berbeda sangat nyata $(\mathrm{P}<0.01)$ terhadap $\mathrm{R} 4$. Lama perlakuan R4 berbeda sangat nyata $(\mathrm{P}<0.01)$ terhadap R0, R1, R2 dan R3. Dari hasil analis data dapat dilihat terjadi peningkatan tingkat kesukaan panelis pada R1, R2 dan R3 tetapi terjadi penurunan pada perendaman R4. Dapat diketahui perendaman daging ayam petelur tua dalam ekstrak kulit nanas selama satu jam mendapatkan tekstur yang terbaik. Hal ini disebabkan semakin lama perendaman dalam ekstrak kulit nanas bekerja dalam daging sehingga protein terdenaturasi dan cairan dalam daging keluar sehingga tekstur daging menjadi lembut. Lawrie (2003), menyatakan bahwa selama proses perendaman daging terjadi proses hidrolisis protein serat otot, dan tenunan pengikat serta terjadi perubahan-perubahan yaitu menipis dan rusaknya sarkolema, terlarutnya nukleus dari serabut otot, jaringan ikat serta lepasnya keterikatan serabut otot sehingga dihasilkan jaringan yang lunak.

\section{Rasa Daging}

Hasil pengamatan rasa daging dapat dilihat pada Tabel 1. Data menunjukkan bahwa tingkat kesukaan panelis terhadap rasa daging dengan lama perendaman yang berbeda dan pada kisaran rataan 2.63 (agak tidak suka) sampai 4.63 (suka).

Hasil sidik ragam menunjukkan bahwa perlakuan lama perendaman daging ayam petelur tua dalam ekstrak kulit nanas berbeda sangat nyata $(\mathrm{P}<0.01)$ terhadap rasa daging. Hasil uji lanjut menggunakan uji wilayah berganda Duncan menunjukkan bahwa perlakuan R0 berbeda sangat nyata $(\mathrm{P}<0.01)$ terhadap R1, R2, R3 dan R4. Lama perendaman R1 tidak berbeda nyata ( $\mathrm{P}>0.05$ ) terhadap R2 dan R3 tetapi berbeda nyata $(\mathrm{P}<0.05)$ terhadap $\mathrm{R} 4$. Lama perendaman R2 tidak berbeda nyata (P>0.05) terhadap R3 dan R4. Lama perendaman R3 tidak berbeda nyata 
( $\mathrm{P}>0.05)$ terhadap R4. Lama perlakuan R4 berbeda nyata $(\mathrm{P}<0.05)$ terhadap $\mathrm{R} 0$ dan $\mathrm{R} 1$ tetapi tidak berbeda nyata $(\mathrm{P}>0.05)$ terhadap R2 dan R3. Dari hasil analisis data dapat diketahui bahwa semakin lama perendaman daging ayam petelur tua dalam ekstrak kulit nanas maka tingkat kesukaan terhadap rasa daging ayam petelur tua semakin menurun diakibatkan rasa sepat daging. Timbulnya rasa sepat disebabkan tanin yang tergandung dalam kulit nanas. Perendaman dalam ekstrak kulit nanas dapat menghidrolisis polipeptida pada lipoprotein sehingga lemak dan zat-zat lain terurai. Kerusakan lemak dapat dipercepat oleh hidrolisis lemak oleh ekstrak kulit nanas yang mengandung bromelin dan bersifat asam (Winarno, 1992). Adapun menurut Amelia dan Habibati (2014), hasil uji untuk tanin pada kulit nanas menghasilkan nilai positif.

\section{KESIMPULAN}

Sifat organoleptik daging ayam petelur tua yang disukai panelis untuk tekstur dan keempukan adalah yang direndam selama satu jam pada ekstrak kulit nanas sedangkan untuk warna, aroma dan rasa adalah yang tanpa perendaman.
Amelia W, dan Habibati. 2014. Identifikasi Senyawa Flavonoid, Tanin, Steroid, Triterpenoid dan Saponin pada Kulit Buah Nanas (Ananas comucus L. Merr). Prodi Kimia FKIP. Universitas Syiah Kuala.

Fenita, Y., O. Mega dan E. Dianti. 2009. Pengaruh pemberian air nanas (Ananas cosumus) terhadap kualitas daging ayam petelur afkir. Jurnal Sains Peternakan Indonesia. 4(1): $1978-3000$

Fernando, D. 2007. Sifat Fisik Dan Organoleptik Daging Ayam Broiler Yang Diberi Pakan Dengan Penambahan Tepung Daun Sambiloto. Skripsi. Program Studi Teknologi Hasil Ternak Fakultas Peternakan. Institut Pertanian Bogor

Ha, M., A. E. A. Bekhit, A. Carne, and D. L. Hopkins, 2012. Characterisation of commercial papain, bromelain, actinidin and zingibain protease preparations and their activities toward meat proteins. Food Chemist. 134(1): 95-105.

Hadiwiyoto, S. 1992. Kimia Pangan. Edisi Kedua. Penerbit ITB. Bandung

Kumaunang, M dan V. Kamu. 2011. Aktivitas enzim bromelin dari ekstrak kulit nanas (Ananas comosus). Jurnal Ilmiah Sains. 11(2): 199-201

Lawrie, R. A. 2003. Ilmu Daging. Terjemahan A. Parakkasi. Universitas Indonesia Press, Jakarta

\section{DAFTAR PUSTAKA}

Mashuri, M. 2014. Isolasi dan pengukuran aktivitas enzim bromelin dari ekstrak kasar bonggol nanas 
(Ananas comosus) pada variasi suhu dan pH. Jurnal Biologi 2(2): 23021616

Naiola, E dan N. Widhyastuti. 2007. Semi purifikasi dan karakterisasi enzim protease Bacillus sp Berk. Penelitian Hayati. (13): 51-56

Purnamasari, E., A. Eltha, D. Febrina dan E. Irawati. 2014. Pemanfaatan kulit nanas (Ananas comosus L. Merr) dalam meningkatkan kualitas ayam petelur afkir. Sagu 13(2): 1412-4424

Rohman, F., E. M. Roisu dan D. A. Hanung. 2015. Pengaruh dosis dan lama perendaman ekstrak nanas (Ananas Comosus L. Merr) terhadap kualitas fisik daging dada ayam petelur afkir. Surya Agritama. 4(1): 36-42

Rugayah, N. 2008. Eksrak Nanas terhadap daging sapi dan kambing. Jurnal Ilmiah Santina. 3(4)

Sebayang, F. 2006. Pengujian stabilitas enzim bromelin yang diisolasi dari bonggol nanas serta imobilisasi menggunakan kappa karagenan. J. Sains Kimia. 10(1): 20-26.

Soeparno. 2015. Ilmu dan Teknologi Daging Edisi Revisi. Universitas Gajah Mada Press, Yogyakarta

Steel, R.G.D dan J.H. Torrie. 1995. Prinsip Dan Prosedur Statistika. Penterjemah Bambang Sumantri. Gramedia Pustaka, Jakarta

Subekti, E. 2010. Meat quality of raw materials nuggets laying chicken rejects. Jurnal Mediagro. 6(2): 3136
Suhermiyati, S dan J. S. Sylvia. 2005. Potensi limbah nanas untuk peningkatan kualitas limbah ikan tongkol sebagai bahan pakan unggas.. Anim. Prod. 10(3): 174178

Winarno, F.G. 1992. Kimia Pangan dan Gizi. PT. Gramedia Pustaka Utama. Jakarta

Wuryanti. 2004. Isolasi dan penentuan aktivitas spesifik enzim bromelin dari buah nanas (Ananas comosus L). JKSA. 7(3): 83-87

Zulfahmi, M. 2010. Daya ikat air, kadar air, $\mathrm{pH}$ dan organoleptik daging layer afkir yang direndam dalam ekstrak kulit nanas (Ananas comosus L. Merr) dengan konsentrasi yang berbeda. Jurnal Peternakan. Volume 9(1) 